\title{
Analysis of Silica Saturation Index (SSI), Scale Formation Rate, and Scale Formation Time Based on Geothermal Production Well Head Pressure at Well "X"
}

\author{
Akhmad Sofyan ${ }^{1 *}$, Hari Sumantri Aka², Bambang Yudho Suranta ${ }^{3}$, \\ Safira Maura Aldira Ratasya ${ }^{4}$ \\ 1,2,3,4Politeknik Energi dan Mineral [PEM] Akamigas, Jln Gadjah Mada No. 38, Cepu 58315
}

\begin{abstract}
Well "X" produces two phases geothermal fluids, are vapours and brines. Further, brines solution may consist of ions that develop scales production, such as Silica, Calcite dan Sulphide. These scales will reduce well production fluids significantly likes barrier inside the tubing. Scale saturation Index [SSI] is the parameter to determine the potency of scale development at a sampling well. Experiment results are shown that the scale will not develop at the Well " $\mathrm{X}$ " regarding the SSI value less than 1.
\end{abstract}

Keywords: Scale, Scale Saturation Index (SSI), Scale Formation Rate, Scale Formation Time

包 akhmads@esdm.go.id

\section{Introduction}

The "Y" field geothermal system is associated with several volcanic eruption centers around Mount "Y". Geothermal manifestations consisting of fumaroles and sulfate hot springs that are directly related to the geothermal system are spread at elevations > 1050 masl, while bicarbonate hot springs and bicarbonate-chloride mixed springs are found in areas with lower elevation. The chloride hot spring located in the north of the area about 12 $\mathrm{km}$ from the geothermal site.

This field has an electricity capacity of $377 \mathrm{MW}$ from 110 wells consisting of 77 production wells, 12 injection wells (brine), 10 injection wells (condensate), 5 monitoring wells, and 6 abandon wells. generation system used is a separated steam cycle consisting of Resource Production Facilities (RPF) and Power Generation Facilities (PGF).
The "Y" field is a geothermal system dominated by water with neutral fluid chemistry. In the initial conditions, the average salinity of liquids is around $1.3 \%$ by weight and the noncondensable gas (NCG) content $<0.4 \%$ wt.

In the initial conditions, the temperatures ranged from 235 to $312{ }^{\circ} \mathrm{C}$. There has been steam phase development in the eastern part of the field due to a decrease in liquid level in areas with peak reservoirs at the highest altitudes. In the other hand, because it is water domination, many wells have experienced a decline in production due to the formation of scale in the production well.

This study will discuss the analysis of the scale saturation index (SSI), the rate of scale formation, and the length of time to form the scale 
to determine the potential size of the scale formation at Well "X" and to predict when the scale can be formed so that preparations can be made to clean the scale faster.

\section{A. Geothermal Scaling \& Prediction}

Deposition scale is a major problem in geothermal production. This condition occurs not only in surface casing and equipment but also, in some cases within the reservoirs. This could result in a marked reduction in production, and consequently could limit the output of geothermal installations. Based on Figure 1. Scale deposition generally exists just above the slotted liner hanger at the bottom of the production case, where the flashing occurred. The rolling boil of hot water bubble causes the deposition of some components to rise and the $\mathrm{pH}$ to change, and consequently to precipitation, of the insoluble. Various types of scales are found in the geothermal field, the most common of which are calcite (CaCO), silica (SiO2) and Sulfides. It presents different behaviors according to the conditions in which they are formed (concentration, temperature, pressure, and $\mathrm{pH}$ ).

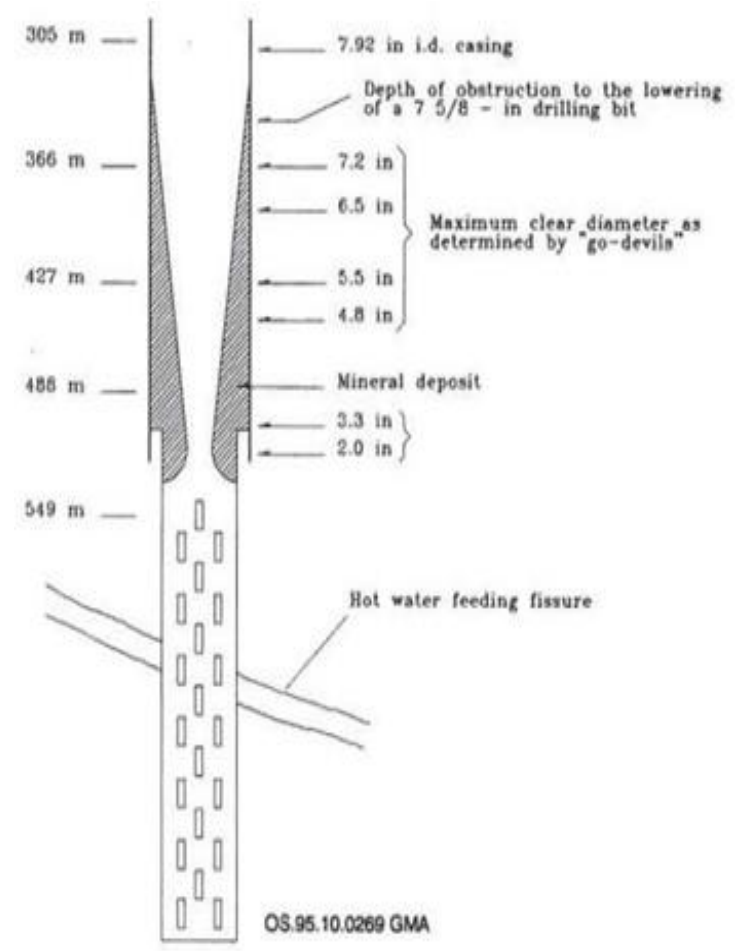

Figure 1. Scale formation in the well (1)

\section{B. Types of Scales in Production Well a. Calcite}

Calcite is a secondary mineral that is common in geotechnology worldwide. It is the most common form of carbonate-bearing minerals in deposits in geothermal wells. Calcium carbonate $(\mathrm{CaCO})$ scale formation in production wells is perhaps the most common scaling problem in geothermal wells. This is related to flashing and the change in $\mathrm{pH}$ that results from degassing. In studies carried out on geothermal scaling, the thickness of the crust ranged from 0.7 to about $3 \mathrm{~cm}$ and resulted in a limiting fluid of 10 to $45 \%$. The estimation of the mass of calcite deposited in the casing of production wells can be estimated using a log caliper. The deposition rate of calcite from several wells can vary widely, depending on the saturation index (S.l.) and liquid composition. Some fluids contain sufficient calcium to properly block the flow of production in a matter of a few weeks.

\section{b. Silica}

Amorphous silica heads up the scaling problem list associated with re-injection of wastewater. Deposited silica in and around the wellbore causes reduced permeability and formation for injection. Some forms of silica deposition have been found in almost all of the hot-enthalpy fields, predominantly liquid, geothermal. The geothermal fluid is extracted and steam separated, sufficient saturation to allow amorphous silica to develop in wastewater. This problem is usually resolved by limiting the number of flashes and temperature to a value above the amorphous silica saturation curve. In practice, this means that the fluid temperature can be reduced to a maximum of several $100^{\circ} \mathrm{C}$ below the reservoir temperature without scaling.

The amorphous silica deposits can then occur by several factors, namely saturation level, temperature, $\mathrm{pH}$, presence of dissolved salts and foreign ions, availability of nucleating types, and fluid flow regime. 


\section{c. Sulfide}

The Sulfide scale is often identified as the source of the problem in the production of large water flows from boreholes, especially in the oil and geothermal industries. This scale occurs in both low and high temperature environments. In high enthalpy geothermal systems, Sulfide minerals are deposited because the concentration of metal cations ( $\mathrm{Fe}, \mathrm{Zn}, \mathrm{Pb}$, etc.) in the liquid is very high due to the presence of chloride complexes and according to the solubility rules. The Sulfide concentration controls the amount of scale formed, that is, the number of deposits is limited by the Sulfide stock in the solution. In some geothermal fields, this scale can be mixed with amorphous silica or with metals (usually iron) [1].

\section{Establishment of Scale in Production Well}

Silica scale that occurs in geothermal production installations can result in losses, namely the scale that is formed will reduce the pipe diameter and inhibit fluid flow. The disruption of the fluid flow causes the equipment to be easily damaged. Silica compounds have several forms, namely quartz, cristobalite, amorphous silica, chalcedony, etc. In the analysis of the potential for silica formation, two relevant forms are used, namely quartz and amorphous silica. In the geothermal reservoir there is a silica equilibrium in the form of quartz according to the reaction:

$$
\begin{aligned}
\mathrm{SiO}_{2(s)}(\text { Quartz }) & +2 \mathrm{H}_{2} \mathrm{O} \\
\leftrightarrow & \mathrm{H}_{4} \mathrm{SiO}_{4}(\text { Silicic Acid })
\end{aligned}
$$

The silica deposition that occurs on the surface (temperature lower than the reservoir temperature) is controlled by equilibrium with amorphous silica which is more soluble than quartz. The solubility of quartz in water which is affected by temperature and salinity can be calculated by [2]:

$$
q(t, m)=q \cdot F(t, m)
$$

Where:

$$
\begin{gathered}
t=(-4.2198 \times 10)+\left(\left(2.8831 \times 10^{-1}\right) q\right) \\
+\left(\left(2.6686 \times 10^{-4}\right) q^{2}\right) \\
+\left(\left(3.1665 \times 10^{-7}\right) q^{3}\right) \\
+(7.7034 \times 10 \log q)
\end{gathered}
$$

$q(t, m)$ : solubility of quartz by temperature and salinity, $\mathrm{mg} / \mathrm{kg} \mathrm{q}=$ solubility of quartz by temperature, $\mathrm{mg} / \mathrm{kg}$; t: water temperature, ${ }^{\circ} \mathrm{C}$ $\mathrm{F}(\mathrm{t}, \mathrm{m})=$ salinity influence factor $\mathrm{m}=$ salinity, molal; $\mathrm{Cl}$ : solubility of the element $\mathrm{Cl}$, ppmw

Meanwhile, the solubility of amorphous silica in water which is influenced by temperature and salinity can be calculated by [2]:

$$
s(t, m)=s \cdot 10^{-m D(t)}
$$

Where:

$\log s=4.52-\frac{751}{t+273}$

$\log D(t)=-1.0596-0.001573 t$

$m=\frac{c l}{35.5 \times 1000}$

Information:

$s(t, m)$ : solubility of amorphous silica by the influence of temperature and salinity, $\mathrm{mg} / \mathrm{kg}$ s: solubility of amorphous silica by the influence of temperature, $\mathrm{mg} / \mathrm{kg} \mathrm{t}=$ water temperature, ${ }^{\circ} \mathrm{C}$

$\mathrm{D}(\mathrm{t})$ : Chen and Marshall's equation $\mathrm{m}=$ salinity, molal

$\mathrm{Cl}$ : solubility of the element $\mathrm{Cl}$, ppmw

An important parameter in relation to silica deposition is the silica saturation index (SSI). SSI is the ratio between the concentration of silica in solution with the solubility of amorphous silica under the same conditions, or if formulated as follows

$$
S S I=\frac{\text { Silica } \text { Larutan Concentration }}{\text { Amorphous Silica Concentration }}
$$


The SSI parameter can be used to estimate its likelihood silica scaling, namely with the following criteria:

a. When SSI> 1, the fluid is supersaturated, and silica deposition is possible.

b. When $S S I=1$, the fluid is saturated.

c. If $\mathrm{SSI}<1$, the fluid is undersaturated, so it is impossible to precipitate silica.

D. Prediction Scale Formation Time a. Saturation index (activity product)

The formation of silica scaling increases with decreasing temperature and increasing $\mathrm{pH}$ due to flashing. The rate of thickening of the silica scaling that occurs in the production pipe and the estimated time of silica scaling that can clog the pipe up to $25 \%$ of the original pipe diameter can be calculated by the following equation [7]:

$S t=\frac{[Q(T 1, m)-s(T 2, m)]}{1743 \times P_{\text {silica }}} \times 365$

$T_{25 \%}=\frac{D}{4 \times S t}$

Where:

$S t$ : Thickening rate of silica scaling (inch / year) $\rho$ silica: Density of silica $=43.442 \mathrm{~g} /$ in 3

$\mathrm{Q}(t 1, \mathrm{~m})$ : solubility of quartz at reservoir temperature ( $\mathrm{t} \_1$ ) and salinity $\mathrm{m} \mathrm{s}(\mathrm{T}, \mathrm{m})=$ amorphous solubility at flashing temperature and salinity $\mathrm{m}$

D: pipe diameter (inch)

\section{Materials and methods}

The data taken are field data Well Pad "X". The following are data and data collection methods needed to carry out this research: (a) Well "X" (Output Curve) test production results, flow rate, and wellhead pressure, (b) Density of silica, solubility of quartz at reservoir temperature, amorphous solution at flashing temperature and salinity. The following is a flow chart of analysis in research:

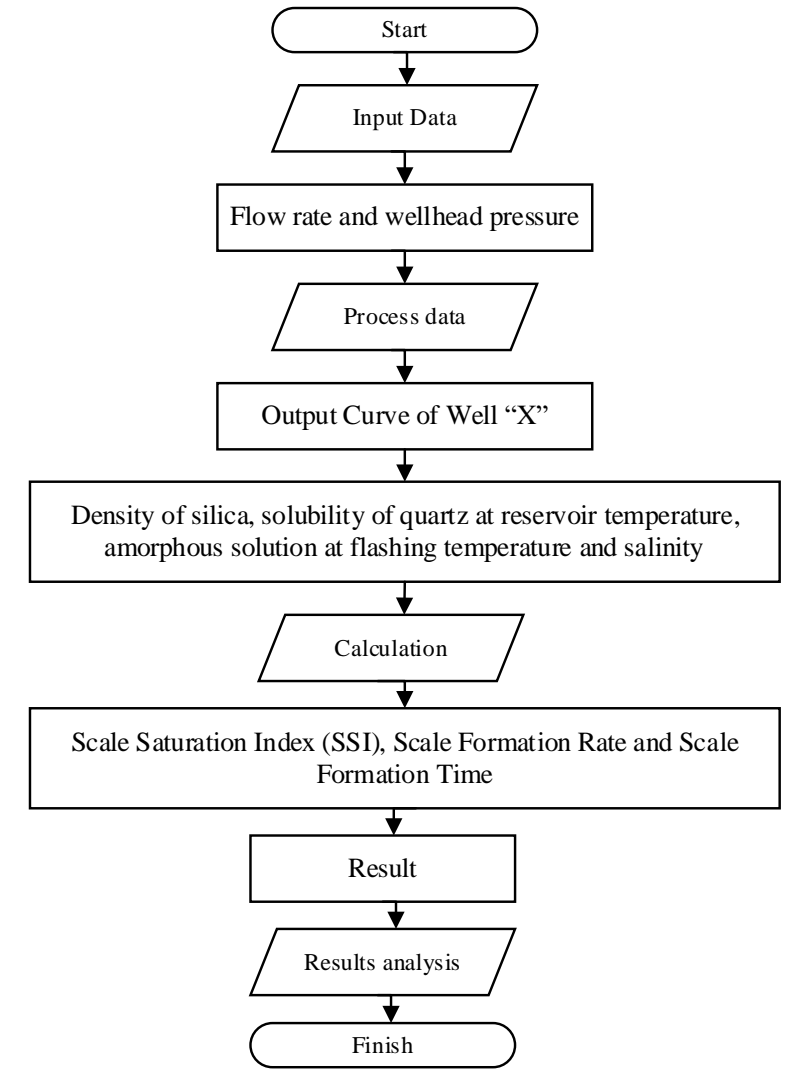

Figure 2. Flow chart of analysis in research

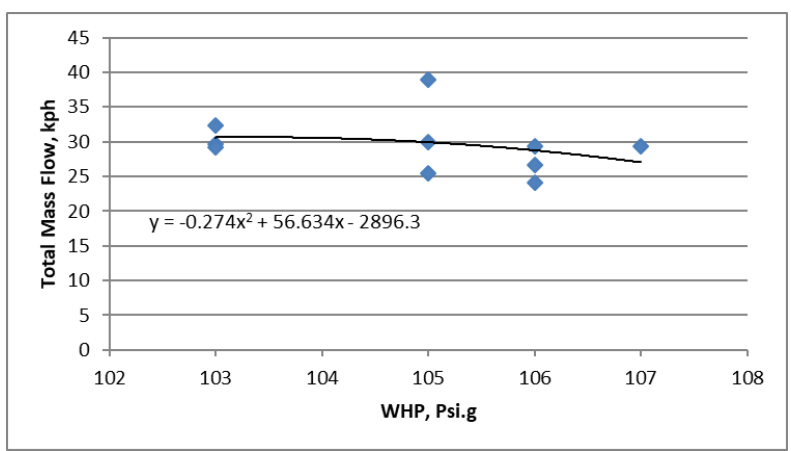

Figure 3. "X" Well Production Test Results

\section{Discussion and Results}

The processing and calculations in this chapter use the following assumptions:

- Evaluation is only based on production test data on the wellhead of the output curve.

- The data from the production test used are the minimum value to the maximum value that can be generated by the well.

- Atmospheric pressure is 0.8 bar or 11.76 psia. 
- The operating pressure of WHP well X was in the range of $103-105$ psi according to the TFT results at that time.

- Consider the potential for silica scaling at the wellhead based on the silica saturation index (SSI).

- In determining electric power (meg-awatt electric) using a specific steam consumption (SSC) or Steam Use Factor co-relation.

Before a geothermal well is produced, it is necessary to measure the production capacity (production test) of the well on the surface in order to determine the amount of fluid mass production that the well can produce.

The production test is carried out by flowing the reservoir fluid to the surface with various flow rates controlled by a system of production test equipment on the surface. The latest well testing uses the tracer and separator dissolution method. The results of the latest production test can be seen in Figure 3.

Based on the graph of Well Production Test Results " $\mathrm{X}$ " above, there is a relationship between well head pressure and mass flow. At the 103 psig well pressure, the resulting flow rate is $32 \mathrm{kph}$, while at higher pressures, 105 psig, the resulting flow rate is $30 \mathrm{kph}$ and at $106 \mathrm{psig}$ the result is a flow rate of $28 \mathrm{kph}$. The smallest flow rate of 26 is generated at the greatest pressure of 107 psig. As mentioned earlier that there is a relationship between mass flow and well head pressure, it can be concluded that the higher the wellhead pressure, the smaller the flow rate. This applies to the opposite that the smaller the wellhead pressure, the greater the resulting flow rate.

Well production test analysis "X" aims to determine the optimal wellhead pressure to produce a flow rate in accordance with well production. The graph above shows the relationship between wellhead pressure and flow rate, from the resulting relationships an analysis of the data can be performed to estimate the amount of wellhead pressure to achieve optimum production results.
The following is the data from the chemical analysis of the Well "X" scale:

Description:

Well: Well "X"

Depth: 2,630 - 4,734 ft MD

$\begin{array}{ll}\text { Analysis Result } & \% \mathrm{w} / \mathrm{w} \\ \text { Quartz (SiO2) } & 10 \\ \text { (Fe, Mg, Zn, Cu, Ni) } & 20 \\ \text { (Fe, Al, Cr) 2O: 12 } & 12 \\ \text { Analcime (NaSi2AlO6.H2O) } & 25 \\ \text { Plagioclase } & 308 \\ \text { Feldspar } & <3 \\ \text { K-Feldspar KASi308 } & <3 \\ \text { Pyrite FeS2 } & <5 \\ \text { Amorphous } & >40 \\ \text { Unidentified } & <5\end{array}$

"Silica Saturation Index (SSI)" is the ratio between the concentration of silica in solution and the solubility of amorphous silica under the same conditions. SSI parameters can be used to estimate the amount of silica scaling, with the following criteria:

- When SSI> 1, the fluid is super-saturated and silica deposition is possible.

- When $\mathrm{SSI}=1$, the fluid is saturated.

- If $S S I<1$, the fluid is undersaturated, so silica precipitation is impossible.

In calculating the saturation silica index in the well-head the data is taken from the production test data with salinity correction. Calculating the SSI value of the Well Head (SSIWH) The SSI value is obtained from the comparison of the solubility of silica with the solubility of amorphous silica under the same conditions, using this equation.

$S S I=\frac{\text { Silica } \text { Larutan Concentration }}{\text { Amorphous Silica } \text { Concentration }} . . . .$.

The concentration value of solution silica and amorphous silica is seen in the wellhead condition with salinity correction, so that the SSI value is:

$S S I=\frac{q(t, m) w h}{s(t, m) w h}$

The following is an example of a wellhead pressure of 2.3479 bar a.

$$
\begin{aligned}
S S I & =\frac{q(t, m) w h}{s(t, m) w h} \\
& =\frac{412.948}{737.3176} \\
& =0.5601
\end{aligned}
$$


Table 1. Calculation Results of SSI Head of Well

\begin{tabular}{|c|c|c|c|c|c|}
\hline \multicolumn{2}{|c|}{} & \multicolumn{2}{c|}{ Wellhead Condition } & \multirow{2}{*}{ SSIWH } \\
\cline { 4 - 6 } WHP & $\begin{array}{c}\text { Silica } \\
\text { (SiO2WH) }\end{array}$ & $\begin{array}{c}\text { AS Correction } \\
\text { (ASWHcor) }\end{array}$ & \multirow{2}{*}{ 's } \\
\hline \hline psig & psia & bara & mg/kg & mg/kg & \\
\hline 103 & 114.76 & 7.81 & 412.95 & 737.32 & 0.56 \\
\hline 105 & 116.76 & 7.94 & 412.28 & 741.85 & 0.55 \\
\hline 106 & 117.76 & 8.01 & 411.94 & 744.10 & 0.55 \\
\hline 107 & 118.76 & 8.08 & 411.61 & 746.34 & 0.55 \\
\hline 103 & 114.76 & 7.81 & 412.95 & 737.32 & 0.56 \\
\hline 106 & 117.76 & 8.01 & 411.94 & 744.10 & 0.55 \\
\hline 106 & 117.76 & 8.01 & 411.94 & 744.10 & 0.55 \\
\hline 105 & 116.76 & 7.94 & 412.28 & 741.85 & 0.55 \\
\hline 105 & 116.76 & 7.94 & 412.28 & 741.85 & 0.55 \\
\hline 26.66 & 38.42 & 2.61 & 452.35 & 502.43 & 0.90 \\
\hline 11.91 & 23.67 & 1.61 & 468.14 & 425.25 & 1.10 \\
\hline 18.08 & 29.84 & 2.03 & 460.70 & 460.42 & 1.00 \\
\hline
\end{tabular}

Based on the table 1, the possibility of silica formation occurs in fluid conditions with more than one SSI. From the table, it can be seen that the greatest possibility of silica formation is at the smallest pressure, namely 11.91 psig with an SSI of 1.10 and for the next largest possible silica formation is at a pressure of 18.08 with an SSI of 1.00 . Whereas at the greatest pressure, which is $107 \mathrm{psig}$, the SSI value is 0.55 and based on the theory, an SSI value of less than 1 has a small possibility of silica formation. Based on the data obtained, it can be concluded that the greater the wellhead pressure, the smaller the SSI produced and the smaller the probability of silica formation.

This applies the opposite. The smaller the wellhead pressure, the greater the SSI price so that the possibility of silica formation will be even greater. From the results of the above analysis, it can be seen that the age head pressure affects the condition of a fluid, both in saturated and unsaturated conditions and the possibility of a fluid to form silica deposits. The probability of a fluid forming silica deposits can be determined from the resulting SSI value at a certain wellhead pressure. Based on table data, the SSI value is inversely proportional to the screw head pressure.

The greater the wellhead pressure, the smaller the resulting SSI value and the less likely it is for a fluid to form silica deposits.
Meanwhile, the smaller the wellhead pressure, the greater the SSI value produced and the greater the possibility of the fluid to form silica deposits.

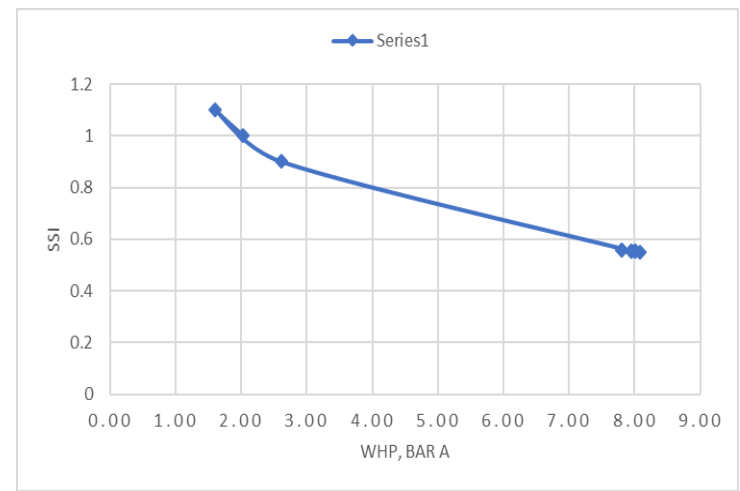

Figure 4. WHP vs SSI graph

Figure 4. found that silica deposits would not form at the WHP that has been used at this time because in that pressure range the SSI value touched $<1$. If the trial and error analysis was carried out, it was found that the SSI value $\approx 1$ was at a pressure of 2.3 bar a or 18.08 psia.

From the above analysis it can be concluded that in fact the well "X" does not have the potential to form a scale or it can also be said that the SSI calculation in the case of the well " $\mathrm{X}$ " cannot be used because the " $\mathrm{X}$ " well does not have a scale potential but a scale is formed. This indicates that there are other causes that cause the scale to form in the " $\mathrm{X}$ " well.

The data needed to predict scale formation $(25 \%)$ are as follows:

$\mathrm{Q}(t 1, \mathrm{~m})=412.948376 \mathrm{mg} / \mathrm{kg}$

$\mathrm{s}(\mathrm{T}, \mathrm{m})=737.3175723 \mathrm{mg} / \mathrm{kg}$

$\rho$ silica $=43.442 \mathrm{~g} /$ inch 3

$\mathrm{D}$, inch $=7.025$ inch

Then input the above data into the following equation to find the reduction rate of silica scaling:

$$
\begin{aligned}
S t & =\frac{[Q(T 1, m)-s(T 2, m)]}{1743 \times P_{\text {silica }}} \times 365 \\
S t & =\frac{[412.948376-737.3175723]}{1743 \times 43.442} \times 365 \\
& =1.563595593 \text { inch } / \text { year }
\end{aligned}
$$


After the thickening rate of silica scaling has been obtained, input this value into the equation below to determine how long it will take for silica scaling to re-form.

$$
\begin{aligned}
& T_{25 \%}=\frac{D}{4 \times S t} \\
& =\frac{7.025}{4 \times 1.563598593} \\
& =1.12321 \text { year }
\end{aligned}
$$

Tabel 2. The results of the calculation of st and $\mathrm{t} 25 \%$

\begin{tabular}{|c|c|c|c|c|c|c|}
\hline \multicolumn{2}{|c|}{} & \multicolumn{2}{c|}{ Wellhead Condition } & \multirow{2}{*}{ st } & \begin{tabular}{c} 
t \\
\multicolumn{2}{|c}{ WHP }
\end{tabular} \\
\cline { 4 - 6 } & $\begin{array}{c}\text { Silica } \\
\text { (SiO2WH) }\end{array}$ & $\begin{array}{l}\text { AS } \\
\text { Correction } \\
\text { (ASWHcor) }\end{array}$ & & \\
\hline psig & psia & bara & mg/kg & mg/kg & $\begin{array}{c}\text { inch/ } \\
\text { year }\end{array}$ & year \\
\hline 103 & 114.76 & 7.81 & 412.95 & 737.32 & 1.56 & 1.12 \\
\hline 105 & 116.76 & 7.94 & 412.28 & 741.85 & 1.59 & 1.10 \\
\hline 106 & 117.76 & 8.01 & 411.94 & 744.10 & 1.60 & 1.09 \\
\hline 107 & 118.76 & 8.08 & 411.61 & 746.34 & 1.61 & 1.09 \\
\hline 103 & 114.76 & 7.81 & 412.95 & 737.32 & 1.56 & 1.12 \\
\hline 106 & 117.76 & 8.01 & 411.94 & 744.10 & 1.60 & 1.09 \\
\hline 106 & 117.76 & 8.01 & 411.94 & 744.10 & 1.60 & 1.09 \\
\hline 105 & 116.76 & 7.94 & 412.28 & 741.85 & 1.59 & 1.10 \\
\hline 105 & 116.76 & 7.94 & 412.28 & 741.85 & 1.59 & 1.10 \\
\hline & & & & & & \\
\hline
\end{tabular}

Based on the Table 2, the largest scale formation rate is at a wellhead pressure of 107 psig with a scale formation rate of 1.61 inch / year and the lowest is at a wellhead pressure of 103 psig of 1.56 inch / year. From these data, it can be seen that the scale will quickly form if the well operates with a wellhead pressure of 107 psig, therefore the well is not operated at the wellhead pressure. Whereas for the longest time to form a scale of $25 \%$, the longest is the 103 psig wellhead pressure of 1.12 years and the fastest $25 \%$ scale formation time is the wellhead pressure of 107 psig with a length of 1.09 years. From these data, it can be seen that the scale will take a long time to form if the well operates at a wellhead pressure of 103 psig, therefore the nozzle is not operated at the wellhead pressure.
From the results of the analysis above, the optimal wellhead pressure has not been obtained. Therefore, analysis is carried out using a graph to obtain the optimal wellhead pressure for the operation of the Well "X" production well.

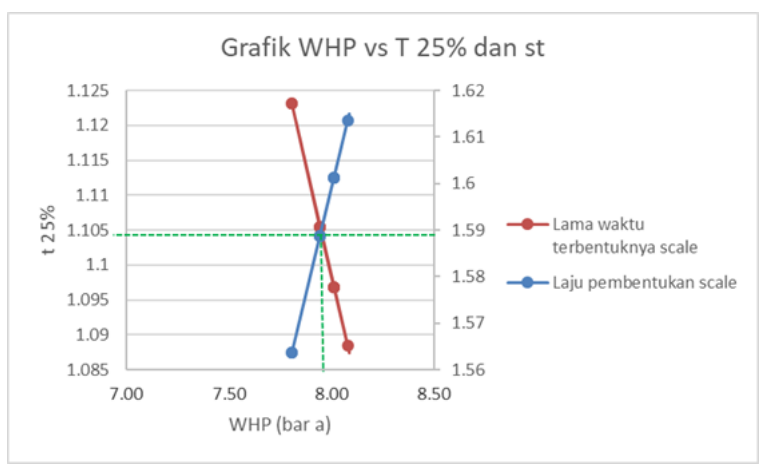

Figure 5. WHP vs st vs t25\% graph

From the results of the calculation and analysis of the graph above, which is Figure 5, it can be concluded that at WHP pressure of 7.81 bar a or 114.64 psig is the best because the scale formation rate is not too large, which is around 1.56 inch / year and the scale formation time of $25 \%$ is more. 1.1232 years.

The theoretical calculation for the well " $\mathrm{X}$ " does not match what happened to the real, because the scale on the well " $\mathrm{X}$ " can be formed in just a few months. This can indicate that something is disturbing the well " $\mathrm{X}$ " so that the scale build time is faster.

\section{Conclusion}

The following are the conclusions of the study as follows:

- From the results of the scale obstruction, the abnormal decline in production is caused by the scale in the depth of the well 2,630 - 4,734 ft MD.

- The type of scale that causes blockage in the well is Silica with a weight of $10 \%$.

- The "X" well does not have the potential for the formation of scaling because the scale saturation index value is $<1$ and because the production fluid flow pattern in the well is annular flow.

- From the Trial and Error analysis, it is found that the SSI value $\approx 1$ is at a pressure of 2.3 bar a or 18.08 psia. 
- At WHP pressure of 7.81 bar a or 114.64 psig is the best because the scale formation rate is not too large, which is around 1.56 inch / year and the scale formation time is $25 \%$, which is longer, which is 1.12321 years.

\section{References}

[1] G. G. M. Argueta, Rehabilitation of Wells With Scaling Problems, Reykjavik: Number 9 Is-108, 1995.

[2] R. A. Dipippo, A simplified Method for Estimating the Silica Scaling Potential in Geothermal Power Plant, United States, 1985.

[3] A. I. P. Moch, Kajian Potensi Silica Scaling Pada Pipa Produksi Pembangkit Listrik Tenaga Panas Bumi (Geothermal), Vol. 07. No. 01. 38-43, 2017.

[4] A. O. Moumin, Geothermal Well Design, Reykjavic: Number 28 Is-108, 2013.

[5] A. Firdaus and A. Pietoyo, Analisa Kelayakan Pembangunan Pembangkit Listrik Tenaga Panas Bumi Studi Kasus: Kamojang, Jawa Barat, Ilmiah Pasti. Volume VI. Edisi 1-Issn 2085-5869, 2012.

[6] A. Firdaus and A. Pietoyo, Analisa Kelayakan Pembangunan Pembangkit Listrik Tenaga Panas Bumi Studi Kasus: Kamojang, Jawa Barat, Bandung: Jurnal Ilmiah Pasti Volume Vi Edisi 1-iSSN 20855869, 2012.

[7] M. A. I. e. a. Permana, Kajian Potensi Silica Scaling pada Pipa Produksi Pembangkit Listrik, Bandung: Jurnal Material dan Energi Indonesia, Vol. 07, No. 01 (2017) $38-43,2017$. 